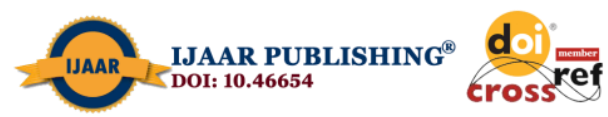

International Journal of Advanced Academic Research | ISSN: 2488-9849

Vol. 7, Issue 4 (April, 2021) | www.ijaar.org

Journal DOI: www.doi.org/10.46654/ij.24889849

Article DOI: www.doi.org/10.46654/ij.24889849.s7457

\title{
FLEXIBLE WORK PRACTICES AND EMPLOYEE RETENTION IN MANUFACTURING COMPANIES IN NIGERIA
}

\author{
Vito Baridula, Ph.D \\ Depart of Management, \\ Faculty of Business Studies, \\ Ignatius Ajuru University of Education, Port Harcourt. \\ Mekuri-Ndimele, Joy Adanma, Ph.D \\ Department of Office and Information Management, \\ Faculty of Business Studies, \\ Ignatius Ajuru University of Education, Port Harcourt.
}

\begin{abstract}
Flexible work practices are very important to improve an employee retention in manufacturing companies in Nigeria. Therefore, the study examined the relationship between flexible work practices and employee retention in manufacturing companies in Nigeria. A cross-sectional research design was adopted in assessing the population of two hundred (200) employees of six (6) manufacturing companies in Nigeria. A sample size of 133 respondents was determined from this population through Krejcie and Morgan (1970) sample table. Primary data were generated through self-administered questionnaire. The reliability of the instrument was achieved through Cronbach Alpha coefficient reliability test and all items scored above 0.70 indicating a reliable research instrument. The hypotheses were tested using Spearman's Rank Order Correlation Coefficient with the aid of Statistical Package for Social Sciences version 23.0. The findings show a positive and significant relationship between flexible work practices and employee retention in manufacturing companies in Nigeria. Thus, the study recommended that manufacturing companies in Nigeria should adopt flexible work practices in order to improve employee retention.
\end{abstract}

Keywords: Flexible Work Practices, Employee Retention, Career Advancement Opportunities Job Autonomy, Promotional Opportunities, Employee Affective Commitment 
Journal DOI: www.doi.org/10.46654/ij.24889849

\section{Introduction}

Organizations are putting in efforts and strategies to recruit and maintain their most important workers. To recruit and maintain workers in the company will need different techniques. Some may agree that getting the right pay is the best technique to improve employee retention but is not the only thing that affects a potential candidate's decision to embrace and remain with a business. Many factors contribute to businesses implementing flexible work strategies, and one of the most debated is employee retention which many corporations are seeking ways to accomplish it. An organization's willingness to keep its staff on board for the long haul is employee retention. Hence, employee retention described the mechanism by which an organization empowers workers to continue for a prolonged period. Employee retention is crucial for companies because it is associated with replacing and retraining new workers (Irshad \& Afridi, 2010), particularly for those who are extremely qualified and hardto-find specialist knowledge (Kreishan \& Al-Hawarin, 2011; Bulut \& Sayin, 2010).

Employee retention is critical to management and in order to achieve firms must develop an atmosphere that allows workers to continue for longer periods of time (Singh \& Dixit, 2011). Employee retention is viewed as a crucial component of maintaining a competitive advantage in the marketplace (Ghansah, 2011). Employee retention is an issue that most companies are struggling with these days. Employing skilled workers for the job is important but maintaining them in their employment is much more important because replacing a new existing employee with a new worker raises operating expenses of fresh new hires and filling positions (Ghansah, 2011). One way to get workers retained is through flexible work practices. With this, employees can work on the go, at home, at a coffee shop, or even while traveling through the help of technological advancement. Employees can reach the office from anywhere using computers, smartphones, and tablets, with cloud-based services controlling the business area. Employers might empower their workers to pursue new positions and embrace new opportunities in order to work flexibly. Allowing workers to work flexibly makes them to feel being part of the organization and not only produces happy and committed employees, but also promotes teamwork and creativity, both of which are key success factors.

Scholars have consistently reflected on the need for flexible work practices for past decades. This represents the increasing importance of flexible work practices. The basic understanding is that flexible work structures allow a company to control its workers and adjust them towards work accomplishments. This is centered on Atkinson's (1984) revolutionary "flexible firm" concept. If flexibility allows organizations to respond to evolving expectations from the environment, the primary problem of flexible work within an organizational context is allocating the work force to the varying consumers' needs or production. Flexibility, from the employee's viewpoint means having the right to choose where to work, for how long and the boss to work with. Several researchers have conducted research on the value of employee retention (Zaffane, 1994) but very few have attempted to examine the relationship between flexible work practices and employee retention in Nigeria. This has demanded more studies in this area to fill this gap. 
Journal DOI: www.doi.org/10.46654/ij.24889849

\section{Statement of the Problem}

Globalization, deregulation, crises, and technological changes have compelled many companies to consider flexible work practices to retain workers and continue to expand and grow capable human resource (Greenwood \& Hinings, 1996). In today's business operations, flexible work practices are neglected. The manufacturing industry's failure to implement flexible work practices has had an impact on workers retention and firm efficiency, resulting in low profitability, low sales volume and poor business growth.

The attitude and behavior of employees in the manufacturing companies in Nigeria denotes absence of employee retention. These are: lack of punctuality, not on seat and refusal to render helping hands to coworkers including high rate of defection. Lack of employee retention can be attributed to a variety of factors. According to Arthur (2001), incompatible corporate cultures, feelings of not being respected or admired, a sense of not being a part of the corporation, insufficient oversight, and a lack of opportunities for advancement are some of the reasons why workers decided to leave an organization. Others include; unequal pay, no fringe benefits, and lack of a flexible work practices. Relationships at work are not working out effectively. The lack of flexible work practices is to be blamed for this. The problem of establishing flexible work practices is a problem for both workers and employers in businesses as competition intensifies. Consequently, firms become immune to issues such as; absenteeism, "not on seats," and other ineffective behaviors that impede the organization's smooth operation (Byrne, 2005). With respect to research performed by different scholars, such as Blake, (2006), Armstrong, (2006), and Sekuguchi, (2004), the most obvious cause for staff leaving is the presence of a downtrodden relationship between workers and their immediate manager which is quite the opposite of retention strategy.

Numerous workers seek to withdraw from an organization because of friction they experienced with their line managers, contrary to the adage "people abandon managers, not organizations." Employees quit their employers for a number of reasons. This resulted in high workplace frustration, causing managerial-level workers to pursue alternate jobs, raising an organization's staff turnover (Yang \& Spector, 2008). Workers quit their employers because they can find a suitable job and same positions in other business entities (Price, 2007). Human resource in an organization is by far the most important, expensive, and unpredictable of all the resources that can be used to achieve the organization's task (Yang \& Spector, 2008).

To really get job going, companies need competent individuals. Today's greatest obstacle for management is recruiting, maximizing, and retaining experienced staff. The rest of today's employers deserve to be allowed to work from home. Flexible work practices are becoming more important as younger people take over the workforce. Employees tend to combine jobs and personal lives, breaking away from the conventional 1-to-5 work days. The root of these problems is traced to lack of adopting flexible work practices. Employees are working under stress and see work as burden which affected their performance. These show the neglect of flexible work practices in Nigerian manufacturing firms. Also, this has created a room for investigation to examine the relationship between flexible work practices and employee retention in manufacturing industry in Nigeria to provide solution to this problem. 


\section{Aim and Objectives of the Study}

The aim of the study is to examine the relationship between flexible work practices and employee retention in manufacturing companies in Nigeria. However, the specific objectives are to:

1. Examine the relationship between career advancement opportunities and employee retention in manufacturing companies in Nigeria.

2. Determine the relationship between job Autonomy and employee retention in manufacturing companies in Nigeria.

3. Ascertain the relationship between promotional opportunities and employee retention in manufacturing companies in Nigeria.

\section{Research Questions}

The following research questions were stated to provide answers to the hypotheses of this study

1. What is the relationship between career advancement opportunities and employees' affective commitment in manufacturing companies in Nigeria?

2. How does job autonomy relate to employees' affective commitment in manufacturing companies in Nigeria?

3. What is the relationship between promotional opportunities and employees' affective commitment in manufacturing companies in Nigeria?

\section{Hypotheses}

The following statements of hypotheses were formulated in null form to guide the study.

Ho: There is no significant relationship between career advancement opportunities and employees' affective commitment in manufacturing companies in Nigeria.

Ho2: There is no significant relationship between job autonomy and employees' affective commitment in manufacturing companies in Nigeria.

Ho3: There is no significant relationship between promotional opportunities and employees' affective commitment in manufacturing companies in Nigeria.

\section{Scope of the Study}

With regards to the content scope, this study only examined literature related to flexible work practices and employee retention. The geographical scope is confined to manufacturing firms in Nigeria. Since the participants are workers of the production industry, the unit of study or analysis was at the micro level. 
Journal DOI: www.doi.org/10.46654/ij.24889849

\section{Significance of the Study}

This study will be of assistance to academics who are involved in broadening their intellectual horizons in this field and contributing to their depth of body of knowledge in this area. This research will assist professionals (managers), businesses and other recipients of knowledge related to flexible work practices and employee retention in coping with circumstances resulting from lack of retaining employee.

The results will support the manufacturing sector in Nigeria because they thoroughly clarified the significance and advantages of flexible work practices in promoting employee retention. The findings and discussion of the concept of flexible work practices will assist manufacturing industry in Nigeria to understand the importance of flexible work practices in retaining employees. Intellectuals that find the result of this study valuable may use it for subsequent research because it will serve as basis for future research on flexible work practices and employee retention. Individuals, academics, and organizations will all learn from the successful results of this research work.

\section{LITERATURE REVIEW}

\section{Flexible Work Practices}

Flexible work activities promote a much greater degree of jobs offered by employers and create opportunities for promotion. Employers offer career development opportunities, work autonomy, and promotional opportunities to workers to improve their retention intent (Ashton $\&$ Sungm 2002). Flexible work practices create sustained performance improvement in organizations and create a better work place especially when workers are satisfied and attain personal achievement. When these two benefits work together, it translates into high level of financial performance, sustained competitiveness and innovation on the part of the firm and increases employee retention.

Flexible workplace practices involve allowing workers to choose when to work, where, and how long they may work either from home or office (World at Work, 2011). Rather than just be working in a tightly controlled workday, flexible work practices encourage workers to have control over time and the environment favorable. Flexible workplace practices include; job sharing, work weekends, yearly hours, flextime, part time work and fixed-term agreements, subcontracting are all forms of this kind of coordination (Brewster \& Tregaskis, 1997).

Flexible work practices look at flextime and enable workers to re-arrange work timings to accommodate them under basic rules, and flex-place. This represents the right of workers to work in the position that is more effective to deliver the task (Hill, 2001). Compressed workweeks, a shortened workload and more holiday days are some of the other choices from which workers can make (DeSivatte \& Guadamillas, 2013). While there are some challenges for the organization in implementing flexible work practices such as rising costs and supervision challenges as well as feelings of loneliness associated with working in remote location which can lead to job discontent (Kelliher \& Anderson, 2008), the benefits are more: it can reduce stress, job enrichment and autonomy, reduce absenteeism, and increase job 
satisfaction and productivity (Russel et al., 2009). Individual and organizations may have the freedom to manage working hours to be productive.

\section{Conceptual Framework}

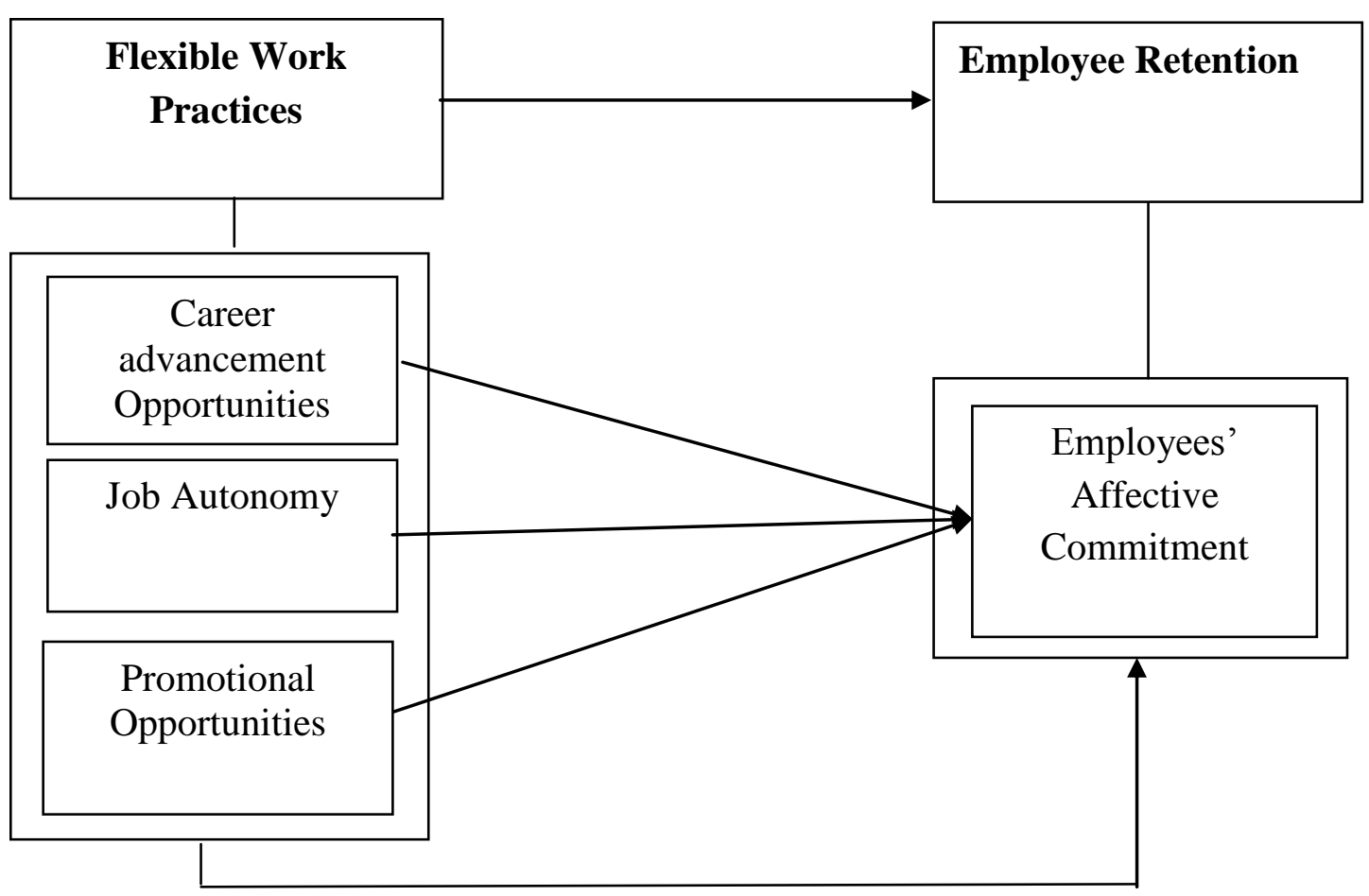

Source: Researcher's conceptualization (2021). Dimensions of flexible work practices by Ashton and Sung (2002). Measures of Employee retention by Marscaux \& Winne. 2013).

\section{Career Advancement Opportunities}

Career advancement, as per McDaniels and Gysbers (1992), is the complete combination of psychological, sociological, cultural, physical, economic, and opportunity influences that converge to shape any given individual's career over the course of their lives. McDaniels and Gysbers (1992) describe career advancement as the products emanating from the communication of individual career planning and institutional career management processes. Career advancement, according to Baer, Flexer, Luft, and Simmons (2008), is a lifelong process that involves childhood growth and transition, systematic career preparation from school, and maturational cycles that occur during a person's working maturity then through retirement. Greenhaus (2003) describes career advancement as the mechanism by which people collect relevant knowledge about their beliefs, talents, abilities, and limitations, determine a career target, and participate in career strategies. Career advancement opportunities improve the possibility of achieving success. Hence, it is expected that career advancement opportunities will improve employee affective commitment in manufacturing firms in Nigeria.

\section{Job Autonomy}

Flexible work processes promote quite greater degree of communication between managers and workers with respect to the required task to be delivered. Job autonomy is the level of 
Journal DOI: www.doi.org/10.46654/ij.24889849

independence and discretion given to individuals over their job and a degree of employee involvement in the firm's planning stage. When it comes to job autonomy, flexible working practices, and other facets of the workplace relates to the degree of flexibility, discretion, and accountability that individuals have over their job (Morgeson et al., 2005).

Workers in a high-autonomy job will determine what, how, and when to complete their job responsibilities. According to previous studies, high work autonomy will provide workers with more time, resources, and flexibility to participate in such activities, increasing their ability and desire to learn and prepare for the future (Humphrey et al., 2005). According to some studies, sovereignty, competence, and relatedness are vital psychological needs which must met in order to promote self-determination (Gagné \& Deci, 2005; Ryan \& Deci, 2000). Among the three, autonomy is the most significant factor. Employees' views of selfdetermination increase as their roles are deemed independent, contributing to a desire to partake in constructive individual developmental practices through job autonomy (Dutton \& Heaphy 2003; Gagné \& Deci, 2005; Ryan \& Deci, 2000; Deci \& Ryan, 2000). Therefore, job autonomy will improve employee affective commitment which in turn leads to employee retention.

\section{Promotional Opportunities}

Promotional opportunities pointed to the flexibility of an organization's practices and the prospect of team members going up the organizational ladder (Delery \& Doty, 1996). According to Accenture (2001), promotion opportunities make workers to be more loyal, happy not to leave firm. According to Miller and Wheeler (1992), workers' decision to stay and work with the organization is motivated by Promotional opportunities expectation. Workers are attracted by the possibility of advancement prospects, considering the fact that hard work goes with reward. In this vein, they developed the feeling of being valued by the organization and show this by their loyalty.

Once an individual passes up the corporate ladder into a state of high accountability, such growth attracts promotion (Dessler, 2009). A work promotion may result in a substantial rise in an employee's pay, power and influence. Employees would be happy with their job if being promoted. Job promotion serves as a motivator and incentive for increased work results as well as other organizational activities. Workers will put in more efforts provided the result will be reward. If they conclude that the decent positions are reserved for newcomers, they would be unmotivated (Pearce, 2011; Poulston, 2008). With this, it could be argued that promotional opportunities will improve employee affective commitment in manufacturing firms in Nigeria.

\section{Employee Retention}

Employee retention relates to an organization's willingness to maintain its workers. Modern meaning relates to customer liking, classification, dedication and confidence, willingness to suggest, and repurchase aim are all recent concepts for the idea of retention (Stauss et al., 2001). According to research, a number of primary factors affect retention, including corporate culture, connectivity, planning, pay and rewards, flexible work schedules, and preparation and professional growth programs. Employee retention, in particular, promotes continuity and links the experience of employees in companies on a daily basis to the organization's vital performance drivers. 
Journal DOI: www.doi.org/10.46654/ij.24889849

Employee retention can be represented by a simple statistic. For instance, if the retention rate is $80 \%$, usually indicate that an organization kept $80 \%$ of its employees in a given period thus, employee retention is achieved. Many consider employee retention as relating to the efforts by which employers attempt to retain employees in their workforce. It is not the effort but the real number of workers preserved successful in the organization which exceeded greatly the number that left the firm in a given period. Employee retention is a difficult concept, as there is no one-size-fits-all approach. Retention has been described in literature as a continuing commitment to do business with a firm (Zineldin, 2000). Maintaining retention of workers is regarded as a critical component of gaining a competitive edge among companies. Thus, retaining workers will do more good than not retaining them.

\section{Employees' Affective Commitment}

Because of its connection to numerous organizational and individual job outcomes such as absenteeism, motivation, and attrition, employee retention has become a hot topic among researchers and practicing managers (Klien et al., 2009). Employee retention is described by Robbins, Judge, and Sanghi (2008) as an employee's willingness to associate with a company to become a member and stick with it, and to fulfill its aims and ambitions. There is a psychological connection between the worker and the organization, as per O'Reilly, Alin, Plisner, Cohen, and Mickee (2003), cited in Uzoma and Worlu (2017). Recognition, compliance, and internalization are also contained in the bond.

Affective committed employees, as Meyer and Allen (1991) quoted in Rhoades, et al. (2001), are those who developed sense of identity and belongingness to a firm and decided to remain with the organization. Previous studies also discovered a correlation between affective commitment and disengagement (Meyer \& Allen, 1991, Mowday et al., 1982). According to Kumari and Froz (2013), high-level committed staff and managers are happier with their lives and careers than low-level workers who are not committed to their organization. They believed that emotional tie is a part of affective commitment and a sense of happiness which is connected with job satisfaction, and the amount of years spent in a company have a positive influence on their live fulfillments. Affective commitment strengthens and attracts an employee's psychological connection to the organization, as well as the employee's working life within it. It involves a worker's personal connection to a company.

When the human resource in the organizations identifies the organizational goal and is willing to pursue them, he will be emotionally attached (Uzoma \& Worlu, 2017). Affective commitment mostly resulted from affirmative psychological feelings toward an organization (O'Reily\& Chatman, 1986). Once an organization's human resource knows its priorities and is able to strive for them, they become personally engaged (Uzoma \& Worlu, 2017). Good psychological emotions about an organization are the most common cause of affective commitment (O'Reily \& Chatman, 1986). Affective commitment is a deep psychological relationship created by people who want to continue with a corporation. According to Gozukara and Yildirim (2015), while workers are handled well by their bosses, they develop favorable feelings about them. This results in a high degree of loyalty. Thus, flexible job practices in the workplace will assist in achieving employee affective commitment in Nigerian manufacturing firms. 
Journal DOI: www.doi.org/10.46654/ij.24889849

\section{Empirical Review}

Previous researchers suggested several factors which facilitate employee retention (Cappelli, 2000). The factors are career opportunities, work environment, organizational justice etc. Employees stay loyal with the organizations that consider these factors (Cole, 2000). According to Osteraker (1999), employee retention is considered the panacea for success of firms because it depends on these factors. Van Knippenberg (2000) claimed that employees will be more loyal if they identify themselves within a group and support a group goal.

Past studies on career advancement have laid emphasizes on just a portion of the career management process. The aspects are known to be the exploratory behavior or career goal setting (Colarelli \& Hartmann, 1983). Other studies of career advancement and development have equally made use of student as samples. Most of these studies of career advancement have used result measures connected to personal effectiveness, like satisfaction with career information and occupational choice (Greenhaus et al., 2000).

The study carried out by Ogini (2020) found a correlation between job promotion and employee engagement in Nigerian public manufacturing firms. In order to investigate the factors, the analysis used a cross-sectional survey. They studied 162 employees from twelve (12) manufacturing firms in Nigeria. As the result shows, there is a significant relationship between work advancement and employee engagement in Nigerian public manufacturing firms.

Morris and Quarles (2004) conducted a study on promotional opportunities and employee intent to stay. From the findings, they conclude that promotional opportunities affect employee intention to stay. Other similarly, researchers have found significant relation between promotion opportunities and performance of employees (Delaney \& Huselid, 1996; Shahzad et al., 2008; Teseema \& Soeters, 2006).

Careem et al. (2913) carried out a study on retention and performance of employees and found that why workers performance were improved is because the organization value them and retained them using all necessary techniques which made workers to develop sense of commitment and intention to stay. Joarder et al. (2011) also found that workers chances for promotion make workers get rid of intention to leave the firm, instead, they develop more committed spirit to work with the firm. Irshad and Afridi (2010), Kwenin et al. (2013) and Luthans (2005) also found that promotional opportunities have a significant relationship with employee retention. From the empirical review, it is obvious that many studies have not been conducted on flexible work practices and employee retention in Nigeria. The few research reviewed were mainly from the foreign environment of which culture in such places might differ in some extent from the domestic environment like Nigeria. This was considered as a gap which led to the present study. Hence, from the review of past scholarly works and the arguments they put forward clearly shows that adopting flexible work practices will improve employee retention in Nigerian manufacturing firms.

\section{Method}

The cross sectional survey of the quasi experimental design was adopted. This stemmed from the fact that cross sectional survey research design is thought of as analogous to the taking of snapshot of some situations and analyzing it (Baridam, 2001). Furthermore, the cross 
Journal DOI: www.doi.org/10.46654/ij.24889849

sectional survey research design relies on a sample of elements from the population of interest which are measured at a single point in time. Finally, it involves using questionnaire in drawing response on the variables under investigation (Baridam, 2001). The target population for this study consists of thirty one (31) registered manufacturing firms in Port Harcourt according to the Manufacturers Association of Nigeria (MAN). Since the unit of analysis of this study is at the organization level, the study focused on 200 respondents consisting of managers, supervisors and employees selected from six (6) registered manufacturing firms using purposive sampling technique. This formed the accessible population for the study.

The firms under review includes; crocodile machete Nig. Ltd $=30$ : Nigerian work engineering Ltd 25: Rivers vegetable oil Co. Ltd $=35$ : Nigerian bottling Co. Plc $=45$ : Sunflower manufacturing company Ltd $=25$ : Oil and industrial Ltd $=40$ : total $=200$ staff strength and were obtained from the human resource department of the various firms. The accessible population of this study is two hundred (200) respondents consisted of managers, supervisors, and employees in six (6) manufacturing firms. Hence, the sample size of 133 was determined using Yamene's formula and Bowley's (1964) allocation formula for strata sampling for each firm. The primary data were collected with the use of questionnaire. Questionnaire was used in the data collection because it gives the respondents time to ponder over the questions before answering them. The researcher gathered the secondary data from literature, journals, articles, annual reports, periodical and books. A detailed questionnaire of one hundred and thirty three in number (133) were prepared and distributed personally to the six manufacturing firms in Port Harcourt with the intention of obtaining useful information from the respondents.

Operational measures of the Study Variables: The dimensions of flexible work practices are career advancement opportunities, job autonomy and promotional opportunities

Career advancement Opportunities: Four (4) item statements were used for the measuring of this variable on Likert 4-points scale; where strongly disagree scored 1-point, disagree scored 2-points, agree scored 3-points and strongly agree scored 4-points.

Job Autonomy: Four (4) item statements were used to measure information sharing on Likert 4-points scale where, response to strongly disagree scored 1-point, disagree scored 2points, agree scored 3-points and strongly agree scored 4-points.

Promotional Opportunities: Four (4) item statements were used in measuring of this variable on Likert 4-points scale; where strongly disagree scored 1-point, disagree scored 2points, agree scored 3-points and strongly agree scored 4-points. Sample items include:

The measure of employee retention (dependent variable) is employees' affective commitment Four (4) item statements were used in measuring of this variable on Likert 4-points scale; where strongly disagree scored 1-point, disagree scored 2-points, agree scored 3-points and strongly agree scored 4-points.

\section{Validation and Reliability of Instrument}

Validity has to do with the inferences that are made about what an observed score measures or represents. Content validity was used to ascertain the content validity; multiple items were 
used in order to cover all aspect of the variables. Reliability is a measure of the internal consistency and stability of a measuring instrument. This is the degree to which a measurement technique can be depended upon to secure consistent results upon repeated application (Weiner, 2007). To ascertain the reliability of the instrument for the study, the Cronbach (1951) Alpha test was applied in computing the test in order to achieve a reliability score of 0.7 or above as proposed by Nunally (1978). Thus, the following results were obtained from the reliability test. Teamwork scored 0.87 ; no. of items $=4$. Information sharing scored 0.82 ; no. of items $=4$. Innovation scored 0.74 ; no. of items $=4$. Business growth scored 0.85 ; no. of items $=4$. Thus, these results show that the research instrument meets the reliability benchmark of 0.7 and above.

Based on the nature of the study, the study used single variable analysis or one variable at a time (univariate analysis) which was done for descriptive purpose frequency distribution by grouping the data on demographic variables of the respondents in terms of gender, age, academic qualifications, position of respondents in the organization and items on the variables in order to provide useful summary through some measure of dispersion such as range, percentage, mean and standard deviation. The bivariate analysis were done to test the relationship between the dimensions of career development and measures of organizational performance as adopted in this work using Spearman's Rank Order Correlation Coefficient statistic The testing was facilitated using Statistical Package for Social Sciences (SPSS) software version 23.0.

\section{Results and Discussion}

$133(100 \%)$ copies of the questionnaires were distributed to managers, supervisors and employees selected from six (6) registered manufacturing firms. Out of the 133(100\%) copies of questionnaire administered, only $122(91.7 \%)$ were retrieved, while 11 copies which is $(8.3 \%)$ were rejected. Thus, the $122(91.7 \%)$ formed the basis of the analysis.

\section{Demographic Data Analysis}

Tables 1 covers the demographic data collected of Section A of the administered questionnaire and presented as shown below:

Table 1. Gender

\begin{tabular}{|l|l|l|}
\hline Response Variables & No of Respondents & Respondents' (\%) \\
\hline Male & 78 & 63.9 \\
\hline Female & 44 & 36.1 \\
\hline Total & 122 & $100 \%$ \\
\hline
\end{tabular}

Source: Field data, (2021).

The Table above shows that $78(61 \%)$ of the respondents were male while the female were 44 representing $36.1 \%$ of the total respondents. It shows that the majority of respondents were male since they had higher respondents' distribution than the female. 
Table 2. Marital Status

\begin{tabular}{|l|l|l|}
\hline Response Variables & No of Respondents & Respondents' \% \\
\hline Single & 65 & 53.3 \\
\hline Married & 57 & 46.7 \\
\hline Total & 122 & 100 \\
\hline
\end{tabular}

Source: Field data, (2021).

Table 2 indicates that 65(53.3) representing single respondents. While the married respondents 57 representing $46.7 \%$ of the total respondents. The single respondents are the highest response rate.

Table 3. Educational Qualification

\begin{tabular}{|l|l|l|}
\hline Levels of Qualifications & Response rate & Percentage \\
\hline Diploma & 34 & 27.9 \\
\hline First Degree & 48 & 39.3 \\
\hline Master's Degree & 32 & 26.2 \\
\hline Ph.D. Degree & 8 & 6.6 \\
\hline Total & 122 & 100 \\
\hline
\end{tabular}

Source: Field data, (2021).

The result on the above indicates that the majority of the respondents (48) are holders of first degree which represents $39.3 \%$ of the total respondents, followed by respondents with diploma $34(27.9 \%$ ) and 32 respondents representing $26.2 \%$ are master's degree holders, while only $8(6.6 \%)$ are Ph.D degree holders.

Table 4. Positions of Respondents.

\begin{tabular}{|l|l|l|}
\hline Positions & Frequency & Valid Percent \\
\hline Top Management & 18 & 14.8 \\
\hline Managers & 22 & 18.0 \\
\hline Supervisor & 28 & 23 \\
\hline Employees & 34 & 44.3 \\
\hline Total & 122 & 100 \\
\hline
\end{tabular}

Source: Fieldwork, (2021).

Table 4 above shows that the top management respondents were 32 representing 13\%, 45 respondents were Managers representing 18\%, respondents who were supervisors were 65 representing $26 \%$, while the junior staff respondents were 108 representing $43 \%$. The analysis shows that majority of the respondents were employees.

\section{Descriptive or Univariate Analysis of the items on the Questionnaire.}

Since it is a Likert's five point scale adopted, the mean as benchmark will become: 
Acceptable Mean $=\frac{1+2+3+4+5}{5}=3.00$. This shows that response to items that meet the

3.00 mean mark is accepted as for the study.

Table 5. Scores of items on study Variables

\begin{tabular}{|l|l|l|l|}
\hline \multicolumn{1}{|c|}{ Item Statistics } & Mean & Std. Deviation & N \\
\hline Career Advancement Opportunities & 3.3020 & 1.18384 & 122 \\
Job autonomy & 3.1560 & 1.20542 & 122 \\
Promotional Opportunities & 3.4040 & 1.34845 & 122 \\
Employees' Affective Commitment & 3.4200 & 1.42258 & 122 \\
\hline
\end{tabular}

Source: SPSS data output. (2021).

From table 5, the mean score of the items were above 3.00 benchmark mean. Hence, it is accepted that the response rates for the four items were positive.

\section{Bivariate Analysis}

\section{Test of Hypothesis One}

$\mathbf{H}_{\text {O1}}$ : There is no significant relationship between career advancement opportunities and employees' affective commitment in manufacturing firms in Nigeria.

\section{Table 6: Correlation between career advancement opportunities and employees' affective commitment}

\begin{tabular}{|c|c|c|c|c|}
\hline \multicolumn{5}{|c|}{ Correlations } \\
\hline & & & $\begin{array}{l}\text { Career } \\
\text { Advancement } \\
\text { Opportunities }\end{array}$ & $\begin{array}{c}\text { Employees' } \\
\text { Affective } \\
\text { Commitment }\end{array}$ \\
\hline \multirow[t]{6}{*}{ Spearman's rho } & \multirow{3}{*}{$\begin{array}{l}\text { Career Advancement } \\
\text { Opportunities }\end{array}$} & Correlation Coefficient & 1.000 & $.873^{\prime \prime}$ \\
\hline & & Sig. (2-tailed) & & .000 \\
\hline & & $\mathrm{N}$ & 122 & 122 \\
\hline & \multirow{3}{*}{$\begin{array}{l}\text { Employees' Affective } \\
\text { Commitment }\end{array}$} & Correlation Coefficient & $.873^{\pi x}$ & 1.000 \\
\hline & & Sig. (2-tailed) & .000 & \\
\hline & & $\mathrm{N}$ & 122 & 122 \\
\hline
\end{tabular}

${ }^{\star *}$. Correlation is significant at the 0.05 level (2-tailed).

The hypothesis stated sought to determine the extent to which career advancement opportunities relate to employees' affective commitment. The result revealed that career advancement opportunities has a strong positive relationship (.873) with employees' affective commitment when $\mathrm{P}$-value $=.000<0.05$. Therefore, $\mathrm{Ho}_{1}$ is rejected and accepted that there is a significant relationship between career advancement opportunities and employees' affective commitment in manufacturing firms in Nigeria. 


\section{Test of Hypothesis Two}

Ho2: There is no significant relationship between Job autonomy and employees' affective commitment in manufacturing firms in Nigeria.

\section{Table 7. Correlation between Job Autonomy and Employees' Affective Commitment}

\begin{tabular}{|c|c|c|c|c|}
\hline \multicolumn{5}{|c|}{ Correlations } \\
\hline & & & Job autonomy & $\begin{array}{l}\text { Employees' } \\
\text { Affective } \\
\text { Commitment }\end{array}$ \\
\hline \multirow[t]{2}{*}{ Spearman's rho } & Job Autonomy & $\begin{array}{l}\text { Correlation Coefficient } \\
\text { Sig. (2-tailed) } \\
\mathrm{N}\end{array}$ & $\begin{array}{r}1.000 \\
122\end{array}$ & $\begin{array}{l}.742^{\pi \times} \\
.000 \\
122\end{array}$ \\
\hline & $\begin{array}{l}\text { Employee's Affective } \\
\text { Commitment }\end{array}$ & $\begin{array}{l}\text { Correlation Coefficient } \\
\text { Sig. (2-tailed) } \\
\mathrm{N}\end{array}$ & $\begin{array}{l}.742^{\wedge} \\
.000 \\
122\end{array}$ & $\begin{array}{r}1.000 \\
. \\
122\end{array}$ \\
\hline
\end{tabular}

**. Correlation is significant at the 0.05 level (2-tailed).

The second hypothesis was stated to examine the extent to which job autonomy relates to employees' affective commitment in manufacturing firms in Nigeria. The result revealed that Job autonomy has a significant and positive relationship of .742 with employees' affective commitment, when the P-value $=.000<0.05$ ). Therefore, the study rejects $\mathrm{Ho}_{2}$ and accepted that there is a significant relationship between job autonomy and employees' affective commitment in manufacturing firms in Nigeria.

\section{Test of Hypothesis Three}

Ho3: There is no significant relationship between promotional opportunities and employees' affective commitment in manufacturing firms in Nigeria.

Table 8. Correlation between Promotional Opportunities and employees' affective commitment

\begin{tabular}{|c|c|c|c|c|}
\hline \multicolumn{5}{|c|}{ Correlations } \\
\hline & & & $\begin{array}{l}\text { Promotional } \\
\text { Opportunities }\end{array}$ & $\begin{array}{c}\text { Employees' } \\
\text { Affective } \\
\text { Commitment }\end{array}$ \\
\hline \multirow[t]{2}{*}{ Spearman's rho } & $\begin{array}{l}\text { Promotional } \\
\text { Opportunities }\end{array}$ & $\begin{array}{l}\text { Correlation Coefficient } \\
\text { Sig. (2-tailed) } \\
\mathrm{N}\end{array}$ & $\begin{array}{r}1.000 \\
122\end{array}$ & $\begin{array}{r}.768^{\prime \prime} \\
.000 \\
122\end{array}$ \\
\hline & $\begin{array}{l}\text { Employee's Affective } \\
\text { Commitment }\end{array}$ & $\begin{array}{l}\text { Correlation Coefficient } \\
\text { Sig. (2-tailed) } \\
\mathrm{N}\end{array}$ & $\begin{array}{l}.768^{\pi x} \\
.000 \\
122\end{array}$ & $\begin{array}{r}1.000 \\
122\end{array}$ \\
\hline
\end{tabular}

The third hypothesis stated focused on the extent to which promotional opportunities relate to innovation. The result revealed that promotional opportunities has a strong positive and significant relationship of 0.768 with employees' affective commitment, when the P-value = $.000<0.05)$. Therefore, the study rejects $\mathrm{Ho}_{3}$ and accepted that there is a significant relationship between promotional opportunities and employees' affective commitment in manufacturing firms Nigeria. 
Journal DOI: www.doi.org/10.46654/ij.24889849

\section{Discussion of Findings}

The finding from the first hypothesis shows that career advancement opportunities have a strong positive relationship (.873) with employees' affective commitment. This finding is supported by the work of Baer et al. (2008) as they see career advancement as a complete combination of psychological, sociological, cultural, physical, economic, and opportunity influences that converge to shape any given individual's career over the course of their lives. This shows that the individuals are guided by their beliefs, talents, abilities, and limitations. They determine a career target, and participate in career strategies that help improve employee affective commitment. From the above, it is clear that career advancement opportunities strongly improve employee retention.

The second hypothesis revealed that job autonomy has a significant and positive relationship with employees' affective commitment. The work by Morgeson et al. (2005) supported this finding. Morgeson et al. (2005) found that when it comes to time management, working practices, and other facets of the workplace, job autonomy relates to the degree of flexibility, discretion, and accountability that an individual has (Morgeson et al., 2005). They also found that workers in a high-autonomy job will determine what, how, and when to complete their job responsibilities. This is to state that high work autonomy will provide workers with more time, resources, and flexibility to participate in such activities, increasing their ability and desire to learn and prepare for the future.

The finding from the third hypothesis revealed that promotional opportunities have a strong positive and significant relationship with employees' affective commitment. This finding is supported by the work of Morris and Quarles (2004), as they empirically studied promotional opportunities and intent to stay. The results revealed a significant positive relation between promotional opportunities and intention to stay. This shows that promotion opportunities make workers more loyal, happy, and less likely to leave the company, resulting in higher retention. Workers' decision to remain with the organization is motivated by hope for the future. Workers are attracted by the possibility of advancement prospects, considering the fact that when employees are rewarded, they feel valued by the company and return this by their loyalty. Once an individual passes up the corporate ladder and into a state of high accountability, this is eluded to as a career promotion that makes many workers to remain with own organization.

\section{Conclusion}

Conclusively, flexible work practices enable employees to work when, where, and for how long they choose, along with the right to work from home. The degree of employee retention depends on how well the flexible workplace practices are adopted to enhance employees' affective commitment through provision of career advancement opportunities, job autonomy and promotional opportunities. Therefore, the study concludes that flexible workplace practices will improve employee retention in manufacturing firms in Nigeria.

\section{Recommendations}

The following recommendations will assist management in manufacturing firms in Nigeria.

1. Management should design a flexible work practice that accommodates provision for career advancement opportunities to enhance employee retention in manufacturing firms in Nigeria. 
2. Management should ensure that employees are given job autonomy, as this will help them to view self-determination as an important factor to increase their roles and deemed independent in carrying out their task, which will lead to employee retention in manufacturing firms in Nigeria.

3. Management should frequently provide promotional opportunities as this will encourage employees stay in the organization.

\section{Contributions to Knowledge}

This study actually examines the effect of flexible work practices on sustained competitive advantage in manufacturing firms in Nigeria. As such, it developed a framework that captured the extent to which flexible work practices will enhance employee retention in literature. Additionally, this helps in expanding the concept of flexible work practices and employee retention which are limited in literature. Hence, scholars can assess the findings and the gap in the present study and use it to improve future research as relates to these concepts. 


\section{References}

Accenture, (2001). The high performance workforce: Separating the digital economy's winners from losers. In the battle for retention Accenture's Study, 1-5.

Armstrong, M. (2006). A handbook of human resource management practice, Tenth Edition, Kogan Page Publishing, London, 264.

Ashton, D. \& Sung, J. (2001). Lessons from abroad, report for the PIU Project on Workforce Development, UK Cabinet Office.

Atkinson, J. (1984). Manpower Strategies for Flexible Organizations', Management, 28-31.

Baer, R. B., Flexer, R. W., Luft, P., \& Simmons, T.J. (2008). Transition planning for secondary students with disabilities. Pearson Education Inc. 109-112.

Baridam, D. M. (2001). Research method in administrative sciences. Sherbrook Associates.

Blake, J. (2006). From protection to innovation: BT's journey in corporate social responsibility.

Blau, P. M. (1964). Exchange and power in social life. John Wiley \& Sons.

Brewster, C. \& Mayne, L. \& Tregaskis, O. (1997). Flexible working in Europe. Journal of World Business, 2, 133-151

Bulut, Y., \& Esin S. (2010). An Evaluation of Entrepreneurship Characteristics of University Students: An Empirical Investigation from the Faculty of Economic and Administrative Sciences in Adnan Menderes University, International Journal of Economic Perspectives, 4(3), 559-568

Byrne, R. M.J. (2005). Precis of the Rational Imagination: How People Create Alternatives to Reality. Behavioral and Brain Sciences, 2-6..

Cappelli, P. (2000). Rethinking Employment'. In Schuler, R.S. and Jackson, S.E. (eds) Strategic Human Resource Management. British Journal of Industrial Relations, $33(4), 563-602$

Carney, D. (1998). Implementing the sustainable rural livelihoods approach' in D. Carney (ed) Sustainable Rural Livelihoods: What contributions can we make? DFID, London,.

Cole, .G.A. (2000). Personal and human resource management, (5 ${ }^{\text {th }}$ Ed.), London: Continuum.

Cronbach, L. J. (1951). Coefficient alpha and the internal structure of tests. Psychometrika, 16(3), 297-334.

De Sivatte, I., \& Guadamillas, F. (2013). Antecedents and outcomes of implementing flexibility policies in organizations. The International Journal of Human Resource Management, 24(7), 1327-1345. 
Delaney, J.T. \& Huselid, M. A. (1996). The impact of human resource management practices on perceptions of organizational performance. Academy of Management Journal, 39(4), 949-969.

Delery, J.E. \& Doty, D. H. (1996). Modes of Theorizing in Strategic Human Resource Management: Test of Universalistic Contingency, and Configurationally Performance Predictions. The Academy of Management Journal, 39(4), 802 -35.

Dessler, D. (2009). A framework for human resource management. 5th edition. Florida International University. Person Education International.

Dutton, J. E.; \& Heaphy, E.D. (2003). The power of high-quality connections. Positioning. Organizational. Scholarsh, 3, 263-278.

Gagné, M. \& Deci, E.L. (2005). Self-determination theory and work motivation. Journal of Organizational. Behaviour, 26, 331-362.

Ghansah, (2011). The Role of Employee Retention on Job Performance: A Case Study of Accra Brewery Company Limited. http://hdl.handle.net/123456789/4480

Gozukara, I. \& Yildirim, O. (2015) Affective commitment and corporate reputation. The effects of attitude towards advertising and trust. Academic Journal of Economic studies, 1(3), 126-147.

Greenhaus, J. G., Callanan, G.A., \& Godshalk, V.M. (2000). Career management. (3rd ed.). The Dryden Press, 97-121.

Greenhaus, J. H. (2003). Career dynamics. Handbook of psychology volume twelve: Industrial and organizational psychology, John Wiley \& Sons, 519-535)

Greenwood, R. \& Hinings, C.R. (1996). Understanding Radical Organizational Change: Bringing together the Old and the New Institutionalism. The Academy of Management Review, 21(4), 1022-1054

Hill, E., Hawkins, A., Ferris, M. \& Weitzman, M.. (2001). Finding An Extra Day A Week: The Positive Influence of Perceived Job Flexibility on Work and Family Life Balance. Family Relations, 50, 49-58. https://doi.org/10.1111/j.17413729.2001.00049.x.

Humphrey, S.E.; Nahrgang, J.D. \& Morgeson, F.P. (2007). Integrating motivational, social, and contextual work design features: A meta-analytic summary and theoretical extension of the work design literature. Journal of Applied Psychology, 92, 13321356.

Irshad, M. \& Afridi, F. (2010). Factors Affecting Retention: Evidence from Literature. Abasyn Journal of Social Sciences, 4(2), 307-339.

Joarder, M. H. R., Sharif, M. Y., \& Ahmed, K. (2011). Mediating role of affective commitment in HRM practices and turnover intention relationship: A study in a developing context. Business and Economic Research Journal, 1(1), 135-58 
Kelliher, Clare \& Anderson, Deirdre. (2008). For Better Or for Worse? An Analysis of How Flexible Working Practices Influence Employees' Perceptions of Job Quality. International Journal of Human Resource Management, 19. 419-431. https://doi.org/10.1080/09585190801895502.

Klein, H. J., Beeker, T. E \& Meyer J. P (2009). Commitment in organizations: accumulated wisdom and new directions. Routledge/Psychology press.

Kreishan, F. \& Alhawarin, I. (2011). Education and economic growth in Jordan: Causality test. International Journal of Economic Perspectives, 5. 45-53.

Kumari, N., \& Afroz, N., (2013). The impact of affective commitment in employees life satisfaction. Global Journal of management and business research, interdisciplinary. 13(7), 1-7.

Kwenin, D. O., Muathe, S. \& Nzulwa, R. (2013). The Influence of Employee Rewards, Human Resource Policies and Job Satisfaction on the Retention of Employees in Vodafone Ghana Limited. European Journal of Business and Management, 5(12), $1-8$.

Luthans, F. (2005). Organizational behavior. McGraw-Hills International Edition. 28.

Marescaux, E., De Winne, S. \& Sels, L. (2013). HR practices and affective organizational commitment: When does HR differentiation pay off? Human Resource Management Journal, 23(4), 329-345.

Martin, A.F., Romero, F.P., Valle, C.R., \& Dolan, S.L. (2001). Corporate business strategy, career management and recruitment: Do Spanish firms adhere to contingency model? Career Development International Journal, 6(3), 149 - 155.

McDaniels, C., \& Gysbers, N. (1992). Counselling for career development. (1st ed.). San Francisco: Jossey-Bass Publishers, 41-52.

Meyer J. P. and Allen, N. J. (1991). Commitment in the workplace: Theory Research and Application. Thousand Oaks; CA Sage.,

Miller, J. G., \& Wheeler, K. G. (1992). Unravelling the Mysteries of Gender Differences in Intentions to Leave the Organization. Journal of Organizational Behaviour, 13,465478

Morgeson, F.P., Delaney-Klinger, K. \& Hemingway, M.A. (2005). The importance of job autonomy, cognitive ability, and job-related skill for predicting role breadth and job performance. Journal of Applied Psychology, 90, 399-406.

Morris, P. W. \& Quarles, N. S. (2004). Intent to leave among geographically isolated branch office employees: An empirical study. The journal of American academy of business, 397-404

Mowday, R. T., Porter, L. W. \& Steers, R. M. (1982). Employee-organization linkages: The psychology of commitment, absenteeism, and turnover: Academic Press.

Nunnally, J. C. (1978). Psychometric theory: McGraw Hill. 
O' Reilly, C.A \& Chatman, J. (1986), Organizational commitment and psychological attachment. The effects of compliance, Identification and internalization of presocial behaviour. Journal of applied Psychology, 71, $492-499$.

Ogini, J.A. (2020) Job promotion and Employee Commitment of Public Hospitals in Rivers State, Nigeria. IIARD International Journal of Economics and Business Management, 6(1), 2-11.

Osteraker, M.C. (1999). Measuring motivation in a learning organization. Journal of Work Place Learning. 3-6

Pearce, D. G. (2011). Toward an integrative conceptual framework of destination. https://doi.org/10.1177/0047287513491334

Poulston, Jill. (2008). Hospitality workplace problems and poor training: A close relationship. International Journal of Contemporary Hospitality Management, 20. 412-427. https://doi.org/10.1108/09596110810873525.

Price, J.L. (2007). Reflections on the determinants of voluntary turnover. International Journal of Manpower, 7, 600-624

Rhoades, L., Eisenberger, R. \& Armeli, S. (2001). Affective Commitment to the Organization: The Contribution of Perceived Organizational Support. The Journal of applied psychology, 86. 825-36. https://doi.org/10.1037/0021-9010.86.5.825.

Robbins, S.P, Judge, T.A \&, Sanghi, S. (2008). Organization Behaviour, Pearson, prentice Hall.

Russell, H., O’Connell, P. J. \& McGinnity, F. (2009). The Impact of Flexible Working Arrangements on Work-Life Conflict and Work Pressure in Ireland. Gender, Work \& Organization, 16(1), 73-97.

Sekiguchi, T. (2004). The Role of Different Types of Person-Organization Fit in Japanese Recruiters' Judgments of Applicant Qualifications: An Experimental PolicyCapturing Investigation. Japanese Association of Industrial. Organizational Psychology Journal, 3-17.

Shahzad, K., Bashir, S. \& Ramay, I. (2008). Impact of HR Practices on Perceived Performance of University Teachers in Pakistan. International Review of Business Research, 4. 302-315.

Singh, S., \& Dixit, P. K. (2011). Employee retention: The art of keeping the people who keep you in business. International Journal of Business and Management Research, 1, $441-448$

Stauss, B., Choinacki, K., Decker, A., \& Hoffman, F., (2001). Retention effects of a customer's club. International Journal of service industry Management, 12(1), 7-19.

Tessema, M. T, Soeters, J.L (2006). Challanges and practices of HRM in developing countries:testing the HRM-performance link in the Eritrean civil service. International Journal of Human Resource, 17(1), 86-105 
Uzoma F. \& Amaeshi Worlu (2017). Effects of Motivation on Workers' Performance of Selected Firms in Abia State, Nigeria1 Dr.

van Knippenberg, D. (2000). Work motivation and performance: a social identity perspective. Applied Psychology: An International Review, 49, 357-371.

Weiner, J. (2007). Measurement: Reliability and Validity Measures, 32-34

World of Work Report (2011). Making Markets Work for Jobs. Published annually by the International Institute for Labour Studies.

Yang, L., Che, H. \& Spector, P. (2008). Job stress and well-being: An examination from the view of person-environment fit. Journal of Occupational and Organizational Psychology, 81. 567-587. 10.1348/096317907X243324.

Zareen, M., Razzaq, K. \& Mujtaba, B. G. (2013). Job Design and Employee Performance: the Moderating Role of Employee Psychological Perception. European Journal of Business and Management, 5(5), 3-6.

Zeffane, R. (1994). Patterns of organizational commitment and perceived management style. A comparison of public and private sector employees. Human Relations, 47(8), 977 1010 .

Zineldin, M. (2000). TRM total relationship management, student literature. 